\title{
BIOCHEMICAL CHANGES DURING CIRCULATORY ARREST UNDER DEEP HYPOTHERMIA
}

BY

\author{
M. P. WRIGHT AND G. HIGGINS
}

From the Nuffield Departments of Surgery and Clinical Biochemistry, The Radcliffe Infirmary, Oxford

At body temperatures between $10^{\circ} \mathrm{C}$. and $15^{\circ} \mathrm{C}$. complete circulatory arrest is relatively safe for periods of 60 minutes or more, giving time for extensive open heart operations. The clinical use of this procedure has far outstripped its full investigation under controlled conditions. The time limit for arrest at any given temperature is not known, nor are the types of damage which will occur at that limit, nor their immediate cause. This is partly because the technique of perfusion is not standardized and the physiology and pharmacology of autonomic control at these temperatures are far from established. In consequence every perfusion is different and the complications and bad results which sometimes occur are so various that it is difficult to establish their cause.

In the Nuffield Department of Surgery at Oxford more than 50 operations have been performed under deep hypothermia with circulatory arrest of between 10 and 85 minutes, using a Mayo-Gibbon pump-oxygenator. The priming blood was collected either into Edglugate (Smith, Brown, Young, and Sealy, 1959; Sharp, Excell, Salzman, and Thorup, 1961) and then heparinized and recalcified before use, or directly into heparin immediately before operation. Morbidity or mortality directly due to perfusion techniques has been minimal (Gunning, 1961; Hodgson and Parkhouse, 1961).

Perfusion rates during cooling and rewarming were based originally on $2.41 . / \mathrm{min} . / \mathrm{sq}$. m. of body area (approximately $70 \mathrm{ml} . / \mathrm{min}$. $/ \mathrm{kg}$. for an adult). During this series a clinical impression was gained that, if a higher perfusion rate was maintained, the patient was better at the end of the perfusion and his own circulation was more readily established. Consequently an investigation was made to see if (1) any damage which might have been done to the patient by this procedure was reflected in measurable biochemical changes in the blood; (2) the use of E.D.T.A. as an anticoagulant had had any adverse effect on the biochemical constituent of the blood; and (3) an inverse correlation could be established between the flow rate achieved during cooling and any of the more obvious possible effects of circulatory arrest, anoxia, acidosis, or hypoglycaemia.

\section{MATERIAL AND MethodS}

Forty-three operations were studied.

Perfusion Rates.-These varied between 40 and $260 \mathrm{ml} . / \mathrm{min} . / \mathrm{kg}$., most being between 80 and $140 \mathrm{ml} . / \mathrm{min} . / \mathrm{kg}$.

In this series a perfusion rate of under $70 \mathrm{ml} . / \mathrm{min}$./ kg. was considered to be low and a rate of 80 or more $\mathrm{ml} . / \mathrm{min} . / \mathrm{kg}$. to be high.

BLood SAMPLES.-Venous samples were taken from the patient before and after perfusion.

Samples were taken from the pump before and during perfusion, generally as follows: pump blood ; mixed pump and patient's blood at $37^{\circ} \mathrm{C}$.; mixed pump and patient's blood at the end of cooling ; first venous blood to return from the patient at the end of circulatory arrest; and mixed pump and patient's blood at the end of rewarming.

MEASUREMENTS.-Blood oxygen saturation was measured with a densitometer calibrated on a saturated sample against a spectrophotometer. On selected samples oxygen and carbon dioxide content was measured by Van Slyke's method.

The $p \mathrm{H}$ of all samples was measured at $37^{\circ} \mathrm{C}$. in a Wynn-Ludbrook electrode (1957); Rosenthal's (1948) factor of 0.0147 unit $/ 1^{\circ}$ C. was used to calculate the $p \mathrm{H}$ of those samples collected at temperatures below $37^{\circ} \mathrm{C}$. This factor gives an approximation to the change in $p \mathrm{H}$ of the blood per degree Centigrade when it is warmed anaerobically from the collecting temperature to $37^{\circ} \mathrm{C}$.

In 20 patients extensive biochemical analyses were undertaken on all samples. These included estimations of blood haematocrit, and plasma sodium, potassium, calcium, magnesium, bicarbonate, chloride, urea, and protein.

Plasma sodium and potassium were estimated by flame photometry using the E.E.L. flame photometer. Plasma calcium and magnesium were estimated by flame photometry using the Unicam S.P. 900 flame photometer.

Plasma urea, chloride, and bicarbonate were estimated by the Auto-Analyzer instrument. 
Plasma proteins were estimated by the method of Weichselbaum (1946).

\section{Results}

Blood Oxygen Saturation and Tension.-Oxygen saturations are not directly comparable between different bloods at different temperatures, but if saturation, $p \mathrm{H}$, and temperature are known, a figure for oxygen tension which is more comparable may be derived from Severinghaus' nomograms (1958). In more than half of the patients cooled below $15^{\circ} \mathrm{C}$. the venous blood at the end of cooling showed $100 \%$ saturation. The others varied down to $94 \%$ saturation. This corresponds to oxygen tensions between 25 and $130 \mathrm{~mm}$. Hg. The first venous return samples varied from 45 to $80 \%$ saturation, giving oxygen tension figures from 9.5 to $25 \mathrm{~mm}$. $\mathrm{Hg}$. These low figures must reflect even lower levels of tissue oxygen tension.

Plasma Electrolytes and Blood PH.-Table I shows the mean and range for 20 patients of the estimations of $p \mathrm{H}$, bicarbonate, chloride, sodium, potassium, and haematocrit at five selected sampling times. These were chosen to show the trend of changes occurring during the periods before, during, and after cooling.

The sodium, chloride, and haematocrit levels did not change significantly during the procedure. There was a slight fall in the plasma potassium concentration at the end of the cooling period and a rise by the end of the period of arrest. The bicarbonate values all fell during the operation, and at the end showed an average concentration more than $4 \mathrm{mEq}$./1. lower than at the beginning.

The uncorrected $p \mathrm{H}$ figures for the first venous return blood, measured at $37^{\circ} \mathrm{C}$., showed a moderate acidosis varying between 6.94 and 7.29 , but when these figures were corrected by the Rosenthal factor to the temperature of collection, they all indicated an alkalosis, the average being 7.52 and the range 7.39 to 7.69. The samples at the end of cooling showed an even greater alkalosis (average 7.62).

Blood anticoagulant: Heparin and Edglugate. -Table II gives the mean and range of values of constituents of 14 samples of E.D.T.A. blood and of six samples of heparinized blood. Each was mixed and oxygenated in the pump before sampling, but the E.D.T.A. blood was also treated with a mixture of calcium and magnesium salts and with heparin.

The E.D.T.A. blood contained decreased plasma chloride and bicarbonate concentrations but greatly increased calcium concentrations. This high calcium concentration persisted during the perfusion period (Table III) but was usually returning to normal by the end of the operation. Much of this calcium is bound to the E.D.T.A. In one patient the bound calcium was estimated. Table IV shows the results. The E.D.T.A.-bound calcium subtracted from the total calcium leaves normal calcium concentrations. In both series the plasma magnesium concentrations were not significantly altered, and other electrolyte concentrations remained within normal limits.

Blood Sugar Concentration.-Blood sugar levels were determined throughout the operative procedure in one patient perfused with fresh heparinized blood. The concentration in the blood at the first venous return from the patient after circulatory arrest was $124 \mathrm{mg} . / 100 \mathrm{ml}$. There was no evidence of hypoglycaemia during cardiac arrest.

Edglugate blood contains added glucose. Whenever the blood sugar was determined for patients in

TABLE I

THE! MEAN] ANDI RANGE OF BLOOD $p H$ AND/PLASMA ELFCTROLYTE CONCENTRATIONS OF 20 PATIENTS DURING OPERATION WITH CIRCULATORY ARREST UNDER DEEP HYPOTHERMIA

\begin{tabular}{|c|c|c|c|c|c|}
\hline & $\begin{array}{l}\text { Before } \\
\text { Perfusion, } \\
\text { Assisted } \\
\text { Respiration }\end{array}$ & $\begin{array}{l}\text { Pump } \\
\left(37^{\circ} \text { C. }\right)\end{array}$ & $\begin{array}{l}\text { End of } \\
\text { Cooling } \\
\text { before Arrest } \\
\left(9-15^{\circ} \mathrm{C} .\right)\end{array}$ & $\begin{array}{c}\text { First Venous } \\
\text { Return after } \\
\text { Arrest } \\
\left(12-17^{\circ} \mathrm{C} .\right)\end{array}$ & $\begin{array}{l}\text { After } \\
\text { Perfusion, } \\
\text { Assisted } \\
\text { Respiration }\end{array}$ \\
\hline $\begin{array}{l}\text { pH (corrected) } \\
\text { Bicarbonate (mEq./1.) } \\
\text { Chloride (mEq./1.) } \\
\text { Sodium (mEq./1.) } \\
\text { Potassium (mEq./1.) } \\
\text { Haematocrit }\end{array}$ & $\begin{array}{c}7 \cdot 40(7 \cdot 29-7 \cdot 58) \\
19(15-27) \\
98 \cdot 5(92-106) \\
132 \cdot 5(128-139) \\
4 \cdot 0(3 \cdot 2-5 \cdot 0) \\
43(34-68)\end{array}$ & $\begin{array}{c}7 \cdot 43(7 \cdot 28-7 \cdot 60) \\
15 \cdot 8(12-21) \\
98 \cdot 3(86-112) \\
135 \cdot 7(127-139) \\
4 \cdot 0(2 \cdot 8-7 \cdot 1) \\
38(35-45)\end{array}$ & $\begin{array}{c}7 \cdot 62(7 \cdot 40-7 \cdot 91) \\
17(9-24) \\
97 \cdot 6(89-107) \\
135 \cdot 6(127-139) \\
3.4(2 \cdot 7-4 \cdot 1) \\
41(36-53)\end{array}$ & $\begin{array}{c}7 \cdot 52(7 \cdot 39-7 \cdot 69) \\
17(8-23) \\
96(88-105) \\
134 \cdot 6(127-141) \\
4 \cdot 8(3 \cdot 5-6 \cdot 1) \\
42(37-52)\end{array}$ & $\begin{array}{c}7 \cdot 37(7 \cdot 12-7 \cdot 48) \\
14 \cdot 6(7-20) \\
98 \cdot 7(90-104) \\
135 \cdot 1(122-144) \\
3 \cdot 5(2 \cdot 6-4 \cdot 4) \\
41(35-47)\end{array}$ \\
\hline
\end{tabular}

TABLE II

THE MEAN AND RANGE OF THE CONCENTRATIONS OF CONSTITUENTS OF DONOR BLOOD USED FOR PRIMING THE PUMP-OXYGENATOR

\begin{tabular}{|c|c|c|c|c|c|c|c|c|c|}
\hline \multirow{2}{*}{$\begin{array}{l}\text { Blood } \\
\text { Urea } \\
\text { (mg. } \\
100 \mathrm{ml} . \text { ) }\end{array}$} & \multicolumn{7}{|c|}{ Blood Plasma } & \multirow{2}{*}{$\underset{p \mathbf{H}}{\text { Blood }}$} & \multirow[b]{2}{*}{$\underset{\text { ocrit }}{\text { Blood }}$} \\
\hline & $\begin{array}{c}\text { Chlor- } \\
\text { ide } \\
\text { (mEq./1.) }\end{array}$ & $\begin{array}{c}\text { Bicarb- } \\
\text { onate } \\
\text { (mEq./1.) }\end{array}$ & $\begin{array}{c}\text { Sodium } \\
(\mathrm{mEq} . / 1 .)\end{array}$ & $\begin{array}{l}\text { Potas- } \\
\text { sium } \\
\text { (mEq./1.) }\end{array}$ & 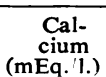 & 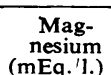 & $\begin{array}{c}\text { Total } \\
\text { Protein } \\
(\text { g. } 100 \mathrm{ml} .)\end{array}$ & & \\
\hline
\end{tabular}

Edglugate blood heparinized and Range $31 \quad 93 \cdot 6$

Fresh heparinized blood $\begin{array}{ll}\text { Mean } \\ \text { Range }\end{array}$ 30
$25-3$
$93 \cdot 6$
$86-100$

14.9
$12-19$ 135
$122-140$

$4 \cdot 5$
$3 \cdot 5-7 \cdot 1$

$109 \cdot 5$

$109 \cdot 5$
$107-112$
138
$133-143$
$3 \cdot 0$
$1 \cdot 8-3 \cdot 3$
10. 1

4.9-14.6

$2 \cdot 0$
$1 \cdot 9-2 \cdot 3$

5.3-5.8

$7 \cdot 38$
$7 \cdot 28-7 \cdot 46$

$4 \cdot 2$
$3 \cdot 5-4 \cdot 8$

$1 \cdot 6$
$1 \cdot 5-1 \cdot 7$
$5 \cdot 5 \cdot 35$
$38 \cdot 7$

$35-45$

38
$37-39$ 
TABLE III

PLASMA CALCIUM AND MAGNESIUM CONCENTRATIONS IN PATIENTS' BLOOD BEFORE OPERATION, AND IN MIXED PATIENTS' AND PUMP BLOOD DURING OPERATION WHEN EITHER E.D.T.A. OR HEPARIN WAS USED AS PRIMARY ANTICOAGULANT FOR COLLECTION OF THE

\begin{tabular}{|c|c|c|c|c|}
\hline & \multicolumn{2}{|c|}{$\begin{array}{l}\text { Plasma Calcium } \\
(\mathrm{mEq} . / \mathrm{l} .)\end{array}$} & \multicolumn{2}{|c|}{$\underset{(\mathrm{mEq} . / 1 .)}{\text { Plasma Magnesium }}$} \\
\hline & Mean & Range & Mean & Range \\
\hline $\begin{array}{l}\text { Before perfusion } \\
\text { During perfusion } \\
\text { with E.D.T.A. }\end{array}$ & $4 \cdot 9$ & $4 \cdot 3-6 \cdot 7$ & $1 \cdot 79$ & $1 \cdot 5-2 \cdot 0$ \\
\hline $\begin{array}{l}\text { blood } \\
\text { During perfusion }\end{array}$ & $7 \cdot 35$ & $4 \cdot 6-9 \cdot 5$ & 1.85 & $1 \cdot 7-2 \cdot 4$ \\
\hline $\begin{array}{l}\text { with heparinized } \\
\text { blood }\end{array}$ & $4 \cdot 65$ & $4 \cdot 0-5 \cdot 2$ & $1 \cdot 70$ & $1 \cdot 5-2 \cdot 0$ \\
\hline
\end{tabular}

TABLE IV

FREE AND E.D.T.A.-BOUND CALCIUM FOUND IN BLOOD DURING OPERATION WHEN EDGLUGATE WAS USED AS ANTICOAGULANT FOR COLLECTION OF THE PUMP-

\begin{tabular}{lccccc} 
& \multicolumn{3}{c}{ PRIMING BLOOD } \\
& $\begin{array}{c}\text { Patient } \\
\text { before } \\
\text { Operation }\end{array}$ & Pump & $\begin{array}{c}\text { Mixed } \\
\text { Patient } \\
\text { and } \\
\text { Pump } \\
\text { Blood }\end{array}$ & $\begin{array}{c}\text { First } \\
\text { Venous } \\
\text { Return }\end{array}$ & $\begin{array}{c}\text { Patient } \\
\text { after } \\
\text { Perfusion }\end{array}$ \\
\hline $\begin{array}{c}\text { Total calcium } \\
\text { (mEq./1.) }\end{array}$ & 4.8 & 8.2 & 8.3 & 8.6 & 7.9 \\
$\begin{array}{c}\text { E.D.T.A.- } \\
\text { bound calcium } \\
\text { (mEq./1.) }\end{array}$ & & 3.2 & 4.0 & 3.5 & 3.3 \\
$\begin{array}{c}\text { Free calcium } \\
\text { (mEq./1.) }\end{array}$ & 4.8 & 5.0 & 4.3 & 5.1 & 4.6
\end{tabular}

whom this blood had been used, the concentration was above the normal level.

\section{Discussion}

Cooling protects the body tissues from damage due to circulatory arrest by slowing metabolic processes. If damage is done, it must be biochemical in nature and should be reflected in changes in the constituents of the venous blood when circulation is restored. The changes might be due to anoxia or carbon dioxide retention, to electrolyte imbalance or metabolic acidosis, or to hypoglycaemia. If any such change were detected, it might give a clue to the type of metabolic upset occurring and to procedures which would minimize the damage.

ANoxiA. - Evidence of anoxia has been presented in this paper. Oxygen saturation in the first venous return after circulatory arrest sometimes fell as low as $50 \%$, corresponding to an oxygen tension of $9.5 \mathrm{~mm}$. $\mathrm{Hg}$.

Carbon Dioxide Retention.-Our results did not indicate any retention of carbon dioxide during the operation. On the contrary, the plasma bicarbonate concentration fell and was on average $4 \mathrm{mEq}$./1. lower at the end than at the start.

Blood Plasma Electrolytes.-Blood haematocrits and plasma levels of chloride, sodium, and potassium remained within normal limits and showed no systematic changes except after circulation had been restarted, when a rise in the plasma potassium occurred. This might indicate cellular damage, but individual figures showed no correlation with other factors, such as duration of arrest or perfusion flow rate.

BLood PH.-The figures for blood $p H$, corrected for the change due to warming the sample anaerobically to $37^{\circ}$ C., showed an alkalosis most profound at the end of cooling and slightly less at the end of circulatory arrest. Rosenthal's correction factor was originally worked out for the correction of blood $p \mathrm{H}$ measured at room temperature to the $p H$ the blood would have shown at $37^{\circ} \mathrm{C}$. It has recently been studied and confirmed by Faulkner (1961). It is being used here in the opposite sense and over a greater range of temperature change. Nevertheless, the error involved is unlikely to be great enough to invalidate our main finding that under our conditions circulatory arrest under deep hypothermia produced an alkalosis rather than an acidosis.

As stated above, the plasma bicarbonate concentration fell during the operation period. The alkalosis observed is probably respiratory in origin, since the patients were usually slightly overventilated whilst on assisted respiration, and while on cardiopulmonary by-pass the carbon dioxide level in the oxygenator was kept as low as $3 \%$ in order to avoid carbon dioxide accumulation. The reduction in alkalosis by $0.1 \mathrm{pH}$ unit at the end of circulatory arrest may indicate some accumulation of acid metabolites other than $\mathrm{CO}_{2}$.

HyPOGLYCAEMIA. - No evidence of hypoglycaemia was detected in the few patients studied in whom heparinized blood was used. The amount of glucose added to the Edglugate blood was sufficient to prevent any low blood sugar concentrations in patients in whom this blood was used.

Edglugate as an Anticoagulant. - The E.D.T.A. in Edglugate acts as an anticoagulant by chelating ionic calcium. It also has affinities for other ions. It was feared that when the pump blood containing E.D.T.A. was of equal or greater volume than the patient's blood, other plasma electrolytes might be seriously disturbed. Our results show no such disturbance, and we had no evidence during the series of any other disturbance due to the use of Edglugate blood.

Anoxia is the only gross metabolic disturbance demonstrated in this investigation. The major factor in the depth of anoxia is the duration of arrest. When allowance was made for this the 


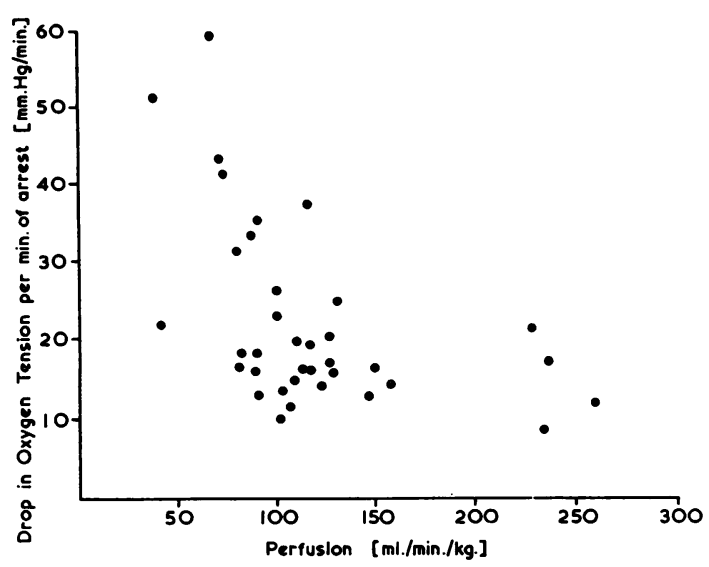

FIG. 1. Oxygen tensions calculated for the first venous b'ood to return from patients after circulatory arrest. Figures have been subtracted from an arbitrary prearrest figure. The difference was divided by the duration of arrest in each case, and then plotted against the appropriate flow rate.

anoxia appeared less when a higher flow rate was maintained during cooling. Figure 1 shows this fall in the oxygen tension of the blood occurring during circulatory arrest. The points, though widely scattered, suggest that there may be an inverse relationship between the depth of anoxia and the rate of flow during cooling. All patients with very high rates of flow showed a small depression of oxygen tension per unit of time; and the patients who had suffered the greatest depression had all had low rates of flow.

There are theoretical reasons why the higher rates of flow may be beneficial.

First, when the oxygenating gas contains high proportions of oxygen, the oxygen tension of the arterialized blood returned to the patient is often as high as $600 \mathrm{~mm}$. $\mathrm{Hg}$; in addition to that combined with haemoglobin, oxygen is carried in direct solution. At low temperatures, a flow of $80 \mathrm{ml} . / \mathrm{min} . / \mathrm{kg}$. is adequate for metabolic requirements and usually the venous blood will return with its haemoglobin still fully saturated, corresponding to oxygen tensions of at least 50 to $130 \mathrm{~mm}$. Hg. If even higher flow rates are maintained the venous oxygen tension may be raised progressively above these levels, and the oxygen tension in the tissues must rise correspondingly, providing a reserve of dissolved oxygen for use during circulatory arrest and reducing any damage due to anoxia.

Second, uneven cooling of the body leaves some parts with a higher metabolic rate and increases anoxia during circulatory arrest. In addition, below about $25^{\circ} \mathrm{C}$. reflex vasomotor control appears to become paralysed and the vascular system becomes passively distensible $(\mathrm{Oz}, \mathrm{Kameya}$, Neville, and Clowes, 1960). It is then important to maintain a physiological level of arterial pressure. This often requires flows considerably greater than those required to maintain gas exchange at normal temperatures, which requirement is the basis of the accepted standard flow rates of $2.41 . / \mathrm{min}$./sq. m. or 50 to $70 \mathrm{ml} / / \mathrm{min}$. $/ \mathrm{kg}$.

At present even cooling is not achieved, and muscle temperatures lag far behind those of the internal organs. But in this series cooling was probably more even in those who had higher flow rates.

\section{SUMMARY}

Biochemical measurements during 43 open heart operations with circulatory arrest under deep hypothermia are reviewed. The limitation of the period of arrest is set by anoxia rather than by acidosis or hypoglycaemia. The technique of perfusion used caused an alkalosis rather than an acidosis, and this alkalosis was probably respiratory in origin. Evidence is given that increased perfusion rates during cooling may reduce the degree of anoxia during arrest, and flow rates considerably higher than those generally accepted may be desirable. Disturbances caused by the use of Edglugate as an anticoagulant were sought but none was found.

Our grateful thanks are due for help and encouragement to Professor P. R. Allison, in whose care the patients were, and to Mr. J. R. P. O'Brian, director of the Department of Clinical Biochemistry, who helped to design the investigation ; to Dr. R. H. Wilkinson, chemical pathologist, to the technical staff of both departments, particularly Miss B. A. Howes and Mr. T. Denton, and to Dr. A. Sharpe for the blood haematocrit determination.

\section{REFERENCES}

Faulkner, W. R. (1961). Cleveland Clin. Quart., 28, 116.

Gunning, A. J. (1961). Thorax, 16, 320.

Hodgson, D. C., and Parkhouse, J. (1961). Brit. J. Anaesth., 33, 303.

Oz, Mustafa, Kameya, S., Neville, W., and Clowes, G. H. A. (1960). Trans. Amer. Soc. artif. int. Organs, 6, 204.

Rosenthal, T. B. (1948). J. biol. Chem., 173, 25.

Severinghaus, J. W. (1958). In Handbook of Respiration, ed. D. S. Dittmer and R. M. Grebe, p. 72. Saunders, Philadelphia.

Sharp, A. A., Excell, B., Salzman, E., and Thorup, O. (1961). In Thrombosis and Anticoagulant Therapy, edited by W. Walker, p. 88. Proc. Symposium held in Queen's College, Dundee, 1960. University of St. Andrews.

Smith, W. W., Brown, I. W., Young, W. G., and Sealy, W. C. (1959). J. thorac. cardiovasc. Surg., 38, 573.

Weichselbaum, T. E. (1946). Amer. J. clin. Path., 16, Tech. Bull., 7 , 40.

Wynn, V., and Ludbrook, J. (1957). Lancet, 1, 1068. 